\title{
HUMAN CORONAVIRUSES. CURRENT STATUS OF THE ISSUE (LITERATURE REVIEW)
}

Varkhomii P. T., student,

Mikheev A. A., PhD, associate professor, Department of microbiology and virology

HSEE of Ukraine „Bukovinian State Medical University”, Chernivtsi-city, Ukraine

DOI: https://doi.org/10.31435/rsglobal_ws/31032020/6976

\section{ARTICLE INFO}

Received: 11 January 2020

Accepted: 20 March 2020

Published: 31 March 2020

\section{KEYWORDS}

coronaviruses,

coronavirus infection,

pathogenesis,

clinical features.

\begin{abstract}
In the 21 st century, when medicine seemed to be steadily progressing and developing, studying and applying new methods of diagnosis and treatment of infectious diseases in order to prevent the occurrence of epidemics, a new infectious agent (virus) of the respiratory system appears, which has the ability of emergence, causes a rather high mortality rate among the population and triggers experts' concern about the unpredictability of the evolution of the virus. This article provides a brief analysis of the literature on coronaviruses and the diseases they can cause in humans, in particular the clinical features in childhood.
\end{abstract}

Citation: Varkhomii P. T., Mikheev A. A. (2020) Human Coronaviruses. Current Status of the Issue (Literature Review). World Science.3(55), Vol.2. doi: 10.31435/rsglobal_ws/31032020/6976

Copyright: (C) 2020 Varkhomii P. T., Mikheev A. A. This is an open-access article distributed under the terms of the Creative Commons Attribution License (CC BY). The use, distribution or reproduction in other forums is permitted, provided the original author(s) or licensor are credited and that the original publication in this journal is cited, in accordance with accepted academic practice. No use, distribution or reproduction is permitted which does not comply with these terms.

Coronaviruses are a genus of viruses that integrate mid-sized pleomorphic RNA-containing viruses that cause coronavirus infection. The sizes range from 80 to $220 \mathrm{~nm}$. Coronaviruses are generally believed to be viruses of infectious bronchitis in birds, although human coronaviruses are also included in this genus. At present, some types of coronaviruses are capable of causing such dangerous diseases as Severe Acute Respiratory Syndrome (SARS), Middle East Respiratory Syndrome-related Coronavirus (MERS-CoV) and the new Coronavirus Respiratory Disease (Covid-2019), caused by new SARS-CoV-2 virus (2019-nCoV), recognized by WHO as a serious outbreak of international concern.

The coronavirus family includes viruses united in two subfamilies of Letovirinae and Orthocoronavirinae.

The subfamily Orthocoronavirinae causes diseases in humans and is divided into genera:

- Genus Alphacoronavirus (11 species);

- Genus Betacoronavirus (9 species);

- Genus Gammacoronavirus (2 species);

- Genus Deltacoronavirus (8 species).

As of March 2020, the following types of human coronavirus infections are known:

a. Human coronavirus $229 \mathrm{E}(\mathrm{HCoV}-229 \mathrm{E})$;

b. Human coronavirus $\mathrm{OC} 43$ ( $\mathrm{HCoV}-\mathrm{OC} 43)$;

c. Severe acute respiratory syndrome coronavirus (SARS-CoV, 2002-nCoV) causes severe acute respiratory syndrome (SARS);

d. Human coronavirus NL63 (HCoV-NL63, New Haven coronavirus);

e. Human coronavirus HKU1 (HCoV-HKU1, 2005-nCoV);

f. Middle East respiratory syndrome-related coronavirus (MERS-CoV, 2012-nCoV or HCoVEMC) causes Middle East respiratory syndrome (MERS, "camel flu");

g. Severe acute respiratory syndrome coronavirus 2 (SARS-CoV-2, 2019-nCoV) causes coronavirus disease (COVID-19). 
The diameter of the coronavirus virions is $75-160 \mathrm{~nm}$. Their morphological feature is the presence of surface club-shaped projections 12-24 nm long, which resemble the solar corona located on the surface of the virion. These projections occur twice less often, which is different from the virions of the influenza virus, easily break off during storage and purification of the virus, and are destroyed by bromelain and trypsin.

The central body and matrix are located in the core of the virion. The central body is a central nucleocapsid with the diameter of $14-16 \mathrm{~nm}$, formed by filaments of $9 \mathrm{~nm}$ in diameter. The matrix is located between the nucleocapsid and the lipoprotein sheath. There are 3 structural proteins in the surface membrane of the virus: membrane protein; transmembrane protein; hemagglutinins.

The virus genome is represented by single-stranded linear RNA, which contains up to 70 polyadenylate sequences at the $3^{\prime}$ end and has a positive polarity. The molecular weight is $5-7 \times 10^{6}$, the sedimentation coefficient is $60-70 \mathrm{~S}$, and the dissociation into fragments with the sedimentation coefficient of $35 \mathrm{~S}$ and $4 \mathrm{~S}$ occurs when heated.

Coronaviruses can affect such systems of the body as respiratory, nervous, and gastrointestinal tract.

The primary reproduction of the virus occurs in the mucous membrane of the nasopharynx and respiratory tract resulting in profuse rhinorrhea, and bronchitis and pneumonia with the subsequent spread of the virus down the respiratory system, especially in children.

The virus is characterized by cytoplasmic replication in humans with a step sequence: the host cell.

1. Attachment of viral S protein to host receptors that mediates endocytosis of the virus into

2. Fusion of the viral membrane with the endosome membrane, $\operatorname{ssRNA}(+)$ is ejected into the cytoplasm.

3. Synthesis and proteolytic cleavage of polyprotein replicase.

4. Replication occurs in "viral factories". The dsRNA is synthesized from the ssRNA(+).

5. The dsRNA gene is transcribed and replicated, thereby providing the formation of new mRNA genomes/new ssRNA(+).

6. Synthesis of structural proteins encoded by subgenomic mRNA.

7. Collection and budding on the membrane of the endoplasmic reticulum - Golgi intermediate compartment.

8. Release of new virions.

Coronaviruses that cause respiratory diseases are represented by OS38 and OS43, and coronaviruses, which lead to enteritis and gastrointestinal disorders are represented by E229 strain.

Coronavirus infection is a viral disease from the group of acute respiratory infections, characterized by the lesions of the upper respiratory tract and a slightly pronounced intoxication with a favorable prognosis for recovery, except for some specific types of the disease such as severe acute respiratory syndrome (SARS), Middle East respiratory syndrome (MERS) and new coronavirus respiratory disease (Covid-2019).

Epidemiological features of the infection are as follows: the source of infection is a patient or virus carrier, the mechanism of transmission is airborne. Susceptibility is extremely high, with $80 \%$ of adults having antibodies to coronaviruses. The peak incidence occurs in the winter months.

\section{Pathogenesis.}

For most coronavirus infections, the incubation period is limited to 2-3 days. However, this period can be 1-14 days (an average of 10 days) for the coronavirus 2019-nCov.

An individual can infect others throughout this period. The course of the disease most often resembles that of the common flu, parainfluenza or any other acute respiratory infection with all the characteristic signs. Characteristic symptoms of coronavirus in the respiratory form are the following: pain in swallowing or sneezing; rhinitis; headache; cough; manifestations of hypoxia; fever; muscle aches.

At the initial stage of infection with a new type of pathogen, the signs of the coronavirus coincide with all the signs of the common cold: dry cough, weakness, fever. Some patients experience eye lesions (conjunctivitis) and diarrhea. If the disease is mild, pneumonia does not develop and all the pathological process is limited to mild symptoms. In such cases, the temperature may rise slightly or remain within the normal range.

In severe forms of the disease, the patient's condition deteriorates rapidly, a very high fever, nonproductive severe cough, and respiratory failure develop. The patient's condition worsens significantly in the presence of comorbidities. 


\section{Features of the disease in children.}

In children, the infection can spread to the lower respiratory tract, causing chest pain when breathing and shortness of breath. Laryngitis, cervical lymphadenitis, hissing respiration, and dry wheezing in the lungs are observed.

Features of the course and complications.

Complete recovery usually occurs in 5-7 days in a common coronavirus. MERS and SARS $\mathrm{CoV}$ usually do not cause complications and disease prognosis is favorable. If the disease is more severe, the recovery may take two weeks or more.

In severe cases, the effects of coronavirus are extremely unfavorable: severe intoxication; the signs of pulmonary edema; progressive acute respiratory failure; multiple organ failure. The prognosis for such course of the disease is unfavorable.

Clinical picture.

According to ICD-10, coronavirus infection is attributed to the block:

- B34.2 "Coronavirus infection not specified";

- B97.2 "Coronavirus infection that causes diseases classified under different headings".

The incubation period is from 2 to 14 days. Clinical manifestations are nonspecific, coronavirus infection can be manifested by the type of disease that causes respiratory syncytial, parainfluenza or rhinovirus infection. Sore throat or pain in swallowing, moderate headache are characteristic signs. The main symptom is rhinitis. Body temperature is normal or subfebrile. There is also cough, chest pain while breathing, difficulty breathing, and wheezing when the lower respiratory tract is affected. These symptoms are thought to indicate certain importance of coronaviruses as agents that contribute to the development of pneumonia.

Prevention of coronavirus infection is mostly non-specific.

\section{REFERENCES}

1. Huang, C., Wang, Y., Li, X., Ren, L., Zhao, J., Hu, Y., ... \& Cheng, Z. (2020). Clinical features of patients infected with 2019 novel coronavirus in Wuhan, China. The Lancet, 395(10223), 497-506.

2. Zhou, P., Yang, X. L., Wang, X. G., Hu, B., Zhang, L., Zhang, W., ... \& Chen, H. D. (2020). A pneumonia outbreak associated with a new coronavirus of probable bat origin. Nature, 1-4.

3. Wang, C., Horby, P. W., Hayden, F. G., \& Gao, G. F. (2020). A novel coronavirus outbreak of global health concern. The Lancet, 395(10223), 470-473.

4. Li, G., \& De Clercq, E. (2020). Therapeutic options for the 2019 novel coronavirus (2019-nCoV).

5. Munster, V. J., Koopmans, M., van Doremalen, N., van Riel, D., \& de Wit, E. (2020). A novel coronavirus emerging in China - key questions for impact assessment. New England Journal of Medicine, 382(8), 692-694.

6. World Health Organization. (2020). Novel Coronavirus ( 2019-nCoV): situation report, 3.

7. Corman, V. M., Landt, O., Kaiser, M., Molenkamp, R., Meijer, A., Chu, D. K., ... \& Mulders, D. G. (2020). Detection of 2019 novel coronavirus (2019-nCoV) by real-time RT-PCR. Eurosurveillance, 25(3).

8. Gralinski, L. E., \& Menachery, V. D. (2020). Return of the Coronavirus: 2019-nCoV. Viruses, 12(2), 135.

9. Уніфікований клінічний протокол первинної медичної допомоги дорослим та дітям. Гострі респіраторні інфекції. Наказ Міністерства охорони здоров’я України від 16 липня 2014 р. № 499.

10. Paules, C. I., Marston, H. D., \& Fauci, A. S. (2020). Coronavirus infections - more than just the common cold. Jama, 323(8), 707-708.

11. Masters, P. S. (2019). Coronavirus genomic RNA packaging. Virology.

12. Fung, T. S., \& Liu, D. X. (2019). Human Coronavirus: Host-Pathogen Interaction. Annual review of microbiology, 73, 529-557. 